\title{
Removal of red- and brown-tide cells using clay flocculation. I. Laboratory culture experiments with Gymnodinium breve and Aureococcus anophagefferens
}

\author{
Mario R. Sengco ${ }^{1, *}$, Aishao Li ${ }^{1}$, Kimberley Tugend ${ }^{2}$, David Kulis ${ }^{1}$, \\ Donald M. Anderson ${ }^{1}$
}

${ }^{1}$ Woods Hole Oceanographic Institution, Biology Department, Woods Hole, Massachusetts 02543, USA

${ }^{2}$ University of South Carolina, Columbia, South Carolina 29208, USA

\begin{abstract}
Twenty-five domestic clays and Loess clay from South Korea were tested for their ability to flocculate and remove cells of Gymnodinium breve (the Florida red-tide organism) and Aureococcus anophagefferens (the New York brown-tide organism). Twelve clay samples, consisting mostly of montmorillonite, bentonite and Florida phosphatic clay displayed removal efficiencies greater than $90 \%$ against $G$. breve at a clay loading of $0.25 \mathrm{~g} \mathrm{l}^{-1}$. Further tests with IMC-P2 phosphatic clay indicated that removal rates can reach as high as $80 \%$ at $0.04 \mathrm{~g} \mathrm{l}^{-1}$. In contrast, the removal values at $0.25 \mathrm{~g} \mathrm{l}^{-1}$ against $A$. anophagefferens did not exceed $40 \%$ for all clays, but increased to $80 \%$ when the clay was dispersed throughout the culture at the time of addition. The removal efficiency of aluminum sulfate (alum), polyaluminum chloride (PAC), and 4 organic flocculants were significantly lower than clays against both organisms (30 to $50 \%$ ). However, the addition of 5 ppm PAC lowered the amount of clay needed for removal of $G$. breve by 1 order of magnitude at low clay concentrations. G. breve fully recovered and remained viable at clay loadings below $0.03 \mathrm{~g}$ $\mathrm{l}^{-1}$, with or without resuspension of the flocs, although their recovery and subsequent growth were delayed by $24 \mathrm{~h}$ compared to untreated cells. High cell mortality (up to $100 \%$ ) and no recovery were observed at clay amounts of $\geq 0.50 \mathrm{~g} \mathrm{l}^{-1}$, even with daily resuspension of the clay/cell pellet. At intermediate clay loadings (e.g. 0.10 to $0.25 \mathrm{~g} \mathrm{l}^{-1}$ ), survival and recovery depended on several factors: clay amount, the frequency of resuspension, or the duration of contact between the cells and clays prior to the first resuspension event. Regardless of clay loading, cell mortality was extremely low (near zero) after $2.5 \mathrm{~h}$ of contact, but increased significantly after $12 \mathrm{~h}$. Preliminary data suggest that cell death may be caused by direct physical contact between the cells and clays and not by the release of potentially cytotoxic substances from the clays or from the lysed cells. Overall, these results show that clays differ substantially in their removal efficiencies, that individual clays differ in their ability to remove different algal species, that flocculants such as PAC can significantly improve clay removal efficiencies, and that the flocculation process can also lead to cell mortality.
\end{abstract}

KEY WORDS: Harmful algal blooms $(\mathrm{HABs}) \cdot$ Clay $\cdot$ Management $\cdot$ Control $\cdot$ Flocculation $\cdot$ Gymnodinium breve $\cdot$ Aureococcus anophagefferens

\section{INTRODUCTION}

Over the past 2 decades, the management of harmful algal blooms (HABs) has focused primarily on the amelioration of their impacts. Current strategies include

*E-mail: msengco@whoi.edu monitoring of HAB cells and toxins, satellite remotesensing, harvesting and sales restrictions for contaminated products, and sometimes the towing of aquaculture pens away from blooms. While these and other programs have enhanced our ability to protect public health and affected resources, there are virtually no strategies in place to limit the proliferation of the cau- 
sative organisms, to prevent an imminent outbreak, or to reduce the threat from an existing bloom. In the US, the most recent attempt to control a natural HAB took place in 1957 when copper sulfate was dispersed by planes over $41.5 \mathrm{~km}^{2}$, stretching along $51.5 \mathrm{~km}$ of the Florida coast, to eradicate massive blooms of Gymnodinium breve (Rounsefell \& Evans 1958). While the strategy reduced the bloom from several locations, toxicity recurred several weeks later. We now know that the recurrence was due to the movement of new bloom patches to shore from an offshore 'source' region. The study concluded that the copper treatment would only give short-term relief from the red-tide/HAB problem. While this negative assessment is valid, such a result (e.g. several weeks without red-tide impacts) may be a desirable outcome in some circumstances, such as in a public health or ecosystem emergency. Important questions that remain about the success or failure of the copper treatment involve the unknown 'collateral' damage to co-occurring organisms. Copper is lethal to many different organisms, so it is highly likely that this treatment caused ecosystem damage that was not assessed.

In the years after this study, direct control strategies including biological, chemical and mechanical bloom control were pursued by only a few investigators (reviewed in Anderson 1997) with the exception of investigators in Japan, who embarked on an extensive series of mitigation studies. Shirota (1989a) summarizes these efforts, many of which were quickly abandoned, but several of which showed promise. One of the most promising investigated the use of clay to control a bloom of Cochlodinium sp. which threatened commercially valuable finfish in aquaculture (Shirota 1989b). A slurry of seawater and montmorillonite was sprayed into and around several fish enclosures to intercept the bloom. Shortly after treatment, the number of red-tide cells at the surface was greatly reduced, water transparency increased, and a marked recovery in the reared opaleye and yellowtail was observed.

In a similar effort, clays were used to treat massive blooms of Cochlodinium polykrikoides in South Korea (Na et al. 1996). In 1996, approximately 60000 t of dry Loess clay (kaolinite type) was dispersed by barges over $260 \mathrm{~km}^{2}$ at a loading rate of $400 \mathrm{~g} \mathrm{~m}^{-2}$. Removal rates of C. polykrikoides were calculated at 90 to $99 \%$ up to $2 \mathrm{~m}$ depth. No mortality in the aquacultured fish species was reported, and the bloom did not return for the remainder of the season. Consequently, Loess clay has been used in subsequent years to control outbreaks along the southern coast of Korea, with some improvements in the methods of clay preparation and dispersal.

The ability of clays to remove algal cells from suspension is based on the concepts of mutual flocculation and sedimentation. Clay minerals dispersed on surface seawater are quickly destabilized due to its high ionic strength. Destabilization is a process by which the repulsive forces on the clay surface are neutralized by an excess of counter-ions. As electrostatic repulsion decreases, attractive forces between particles dominate (e.g. van der Waals forces), and flocculation occurs when the clay particles collide and coalesce to form larger particles (or flocs). The descending flocs then interact with cells, which either flocculate with the clays or are captured as the flocs sweep through the medium. More detailed studies on the possible mechanisms of clay-cell flocculation have been pursued by several workers (Avnimelech et al. 1982, Soballe \& Threlkeld 1988, Yu et al. 1994a,b).

Given the results in Asia, the use of clays to eradicate an exisiting $\mathrm{HAB}$ is a promising and attractive directcontrol option for locations with persistent HAB problems. Aside from their effectiveness, clays are appropriate for this purpose because they are generally inexpensive, readily available in large quantities, and easy to use in field operations. In addition, clays are thought to be substances with little or no direct toxic effects on aquatic organisms (e.g. Howell \& Shelton 1970, Portman 1970, McIntyre 1983). Moreover, marine organisms are most probably adapted to varying amounts of clay minerals in their environment, since clays are a natural and common constituent in river run-off or resuspended bottom sediment. Unfortunately, there were no studies on the environmental impacts of clays in the Asian trials to confirm or reject these assertions. Efforts are underway in South Korea (H. G. Kim pers. comm.) and in our laboratory (authors' unpubl. data) to focus on the impacts of clays on planktonic and benthic communities and on the surrounding water chemistry.

The purpose of this study was to determine the removal efficiency of various domestic clays against 2 HAB species from the USA (Gymnodinium breve and Aureococcus anophagefferens), and to conduct further studies using the most effective minerals. G. breve is a naked dinoflagellate responsible for the recurrent blooms along the west coast of Florida and Texas, and occasional outbreaks in North Carolina, Louisiana and Mississippi (Tester \& Steidinger 1997). The cells produce brevetoxin, the potent neurotoxin which kills fish and marine mammals (e.g. manatees; Landsberg \& Steidinger 1998), contaminates shellfish, and causes respiratory problems in humans as a result of toxins in seaspray. A. anophagefferens is a tiny, non-motile chrysophyte that forms the 'brown tides' in the bays of eastern Long Island (New York), Narragansett Bay (Rhode Island) and Barnegat Bay (New Jersey) (Cosper et al. 1990). Due to their extremely high biomass (up to $1 \times 10^{9}$ cells ml ${ }^{-1}$ ), these blooms have major impacts on Long Island ecosystems and have decimated the bay scallop industry since the mid-1980s. 
In addition, the removal efficiency of clays was compared to that of chemical coagulants and flocculants which are commonly used in water treatment to remove fine suspended material. Additional tests were conducted to determine if further enhancement of $\mathrm{HAB}$ removal would result from combining clays with coagulants and surfactants and through agitation of the clay-algae suspension. Finally, the effect of clay treatment on cell growth and viability of Gymnodinium breve was studied using vital stains and culture experiments.

\section{MATERIALS AND METHODS}

Cultures. Gymnodinium breve (Wilson strain, CCMP 718) and Aureococcus anophagefferens (Clone BP3B, provided by E. Cosper) were grown in batch cultures using modified f/2-Si medium under conditions described by Anderson et al. (1999). Growth was monitored using in vivo cellular fluorescence (Model 10-AU Fluorometer, Turner Designs, Sunnyvale, CA, USA) calibrated against direct microscope cell counts (Avnimelech et al. 1982). Removal experiments were performed using cultures in early to mid-exponential growth.
Clay samples and preparation. Twenty-five clay samples were obtained from various US producers and mining operations; Loess clay was obtained from the G. S. Corporation, Seoul, South Korea (Table 1); Most samples were provided as fine mineral powder which were used directly in removal experiments. Southwestern montmorillonite (SW-M), Golden Cat Sized Product (GC-SP) and Golden Cat Dyer Mill (GC-DM) were ground by hand with a mortar and pestle, and then sieved to obtain powder of between 20 and $74 \mu \mathrm{m}$. For the removal experiments, a clay slurry was prepared by suspending a known mass of clay powder in distilled/deionized (DI) water. Freshwater was chosen over seawater as a carrier to minimize the premature flocculation of the clay slurry by salt ions. Three phosphate mining companies from central Florida provided 5 samples of 'phosphatic clay' dispersed in freshwater containing between 3 and $42 \%$ solids (clay-sized and non-clay sized particles) (Table 1). The percent solid content of the slurry was determined by drying a known mass of wet clay overnight in a laboratory oven $\left(80^{\circ} \mathrm{C}\right)$, then dividing the dry weight by the wet weight. Phosphatic clay suspensions for experiments were prepared by diluting the stock solution to the desired concentration using distilled/DI water.

Table 1. Clay samples tested against Gymnodinium breve and Aureococcus anophagefferens: 25 domestic clay samples, and Loess clay (South Korea). Clays were grouped according to similarities in removal efficiency based on linkage distances in a cluster analysis (Statistica 5.0, Statsoft Inc, Tulsa, UK, USA). First 2 columns group clays based on their removal efficiency of G. breve (Gymno, G) and A. anophagefferens (Aureo, A), respectively (Fig. 1)

\begin{tabular}{|c|c|c|c|c|c|}
\hline Gymno & Aureo & Code & Trade name & Clay mineral type & Company \\
\hline G1 & A3 & MI-BG & Basco Gel & Bentonite & Milwhite, Inc. \\
\hline G1 & A4 & SW-NM & Nicole Mountain & Zeolite & Southwest Mining Group \\
\hline G1 & A3 & WB-B & Big Horn Bentonite & Sodium bentonite & Wyo-Ben, Inc. \\
\hline G1 & A2 & H-DP & Huber DP-1010 & Chemically treated kaolin & J. M. Huber Corporation \\
\hline G1 & A3 & CI-200 & Suspengel 200 & Sodium Western bentonite & CIMBAR performance minerals \\
\hline G1 & A3 & CI-325 & Suspengel 325 & Sodium Western bentonite & CIMBAR performance minerals \\
\hline G1 & A3 & SP-B & Spinks Gel Bentonite & Black Hills bentonite & H. C. Spinks Clay Company, Inc. \\
\hline G1 & & IMC-P1 & Phosphate Rock & Smectite mixture, & IMC-Global Operations, Inc. \\
\hline G1 & A3 & IMC-P2 & & Carbonate-fluorapatite, & IMC-Global Operations, Inc. \\
\hline G1 & & IMC-P3 & & Palygorskite, mica, & IMC-Global Operations, Inc. \\
\hline G1 & & FIPR & & Kaolinite, quartz, wavelite & Florida Institute of Phosphate Res \\
\hline G1 & & NU & & Crandellite, dolomite & Nu-Gulf, Mulberry Corporation \\
\hline G2 & A2 & MI-HY & HY Basco Salt Mud & High-yield attapulgite & Milwhite, Inc. \\
\hline G2 & $\mathrm{A} 3$ & MI-REV & Rev-Dust & Calcium montmorillonte & Milwhite, Inc. \\
\hline G2 & A3 & SW-M & Montmorillonite & Montmorillonite & Southwest Mining Group \\
\hline G2 & A3 & SW-B & Bentonite & Sodium bentonite & Southwest Mining Group \\
\hline G3 & A3 & $\mathrm{H}-90$ & Polygloss-90 & Wrens waterwash kaolin & J. M. Huber Corporation \\
\hline G3 & A3 & GC-DM & Dryer and Mill Dust & Cat litter & Golden Cat, King William, VA \\
\hline G3 & A4 & GC-SP & Sized Product & Cat litter & Golden Cat, King William, VA \\
\hline G4 & A1 & LO & Loess Clay & & South Korea \\
\hline G4 & A3 & MI-K & Kaolinic & Kaolinite and lesser minerals & Milwhite, Inc. \\
\hline G4 & A3 & SP-K & Ball Clay & Kaolinite & H. C. Spinks Clay Company, Inc. \\
\hline G4 & A3 & $\mathrm{SE}-\mathrm{CC}$ & Crown Clay & Kaolin & Southeastern Clay Company \\
\hline G4 & A4 & SW-ZP & Zeo-clino & Zeolite & Southwest Mining Group \\
\hline G4 & A4 & SW-NZ & Natur-Zeo & Zeolite & Southwest Mining Group \\
\hline G4 & A3 & H-35 & Huber-35 & Huber waterwash kaolin & J. M. Huber Corporation \\
\hline
\end{tabular}


Clay screening and comparison. Ten milliliters of cell culture was placed in triplicate borosilicate test tubes (14 mm inner diam.). The initial cell concentration was determined from in vivo cell fluorescence, and concentrations of 7000 to 10000 cells ml ${ }^{-1}$ for Gymnodinium breve and 3 to $5 \times 10^{6}$ cells $\mathrm{ml}^{-1}$ of Aureococcus anophagefferens were routinely used. One milliliter of clay slurry was added dropwise to the surface of the cell suspension using an air-displacement pipet (11 ml final volume). In this set of experiments, the final clay loadings were $0.25,0.5,1.0,2.0$, and $4.0 \mathrm{~g} \mathrm{l}^{-1}$. One milliliter of distilled/DI water was added to the controls. The clay-cell suspension was allowed to flocculate at $20^{\circ} \mathrm{C}$ for $2.5 \mathrm{~h}$ under quiescent conditions. Afterwards, the supernatant directly above the pellet (here defined as the upper $10 \mathrm{ml}$ ) was carefully transferred to a new test tube, mixed, and the number of remaining cells was estimated by fluorescence. The removal efficiency (\%RE) was then calculated using the following equation:

$$
\% \mathrm{RE}=1-\frac{\text { final fluorescence }}{\text { final fluorescence of control }} \times 100
$$

The final fluorescence of the control (i.e. $2.5 \mathrm{~h}$ after the addition of DI water) was used to account for cell sinking. Removal efficiency was plotted against clay concentration for each clay. To select the most efficient clays for each organism, defined here as the sample displaying the highest removal efficiency at the lowest clay dosage $\left(0.25 \mathrm{~g} \mathrm{l}^{-1}\right)$, the initial slope of the removal curve was calculated. The clays were ranked according to this value and they were grouped according to linkage distances using cluster analysis (Statistica 5.0, Statsoft Inc., Tulsa, OK, USA).

Coagulants and flocculants. In these experiments, the ability of coagulants and flocculants to induce cell flocculation was tested. These chemicals are commonly used to enhance the clarity of drinking water by promoting the rapid flocculation of very fine, slow-settling particles or colloids. Coagulants (e.g. aluminum sulfate [alum] and polyaluminum chloride [PAC] neutralize the surface charge of particles, reducing the electrostatic repulsion between them to promote their aggregation. By contrast, flocculants (e.g. long-chain organic polymers with reactive ends) function as interparticle bridges, linking particles together which would normally repel one another. Using the screening protocol above, the removal efficiency of 2 coagulants (alum and PAC) and 2 cationic flocculants (Percol LT7990 and LT-7991) were tested against Gymnodinium breve. Also, alum, PAC and 2 flocculants (Percol 720 (nonionic) and Percol 778 (cationic)) were tested against Aureococcus anophagefferens. The coagulants/flocculants were prepared using distilled/DI water and added to the cell suspension to a final concentration of 0 (DI water only), 1, 10, 100, 1000 ppm.
Combination of coagulants/flocculants and clays. To determine whether coagulants and/or flocculants can enhance the removal efficiency of clays against Gymnodinium breve, increasing amounts of IMC-P2 (phosphatic clay) and SW-NZ (zeolite) were mixed with 1, 10, 100, 1000 ppm of alum, Percol LT-7990 and Percol LT-7991 just prior to the screening protocol. IMC-P2 was also treated with 5 ppm PAC. In the same fashion, H-DP (kaolin), MI-HY (attapulgite) and IMCP2 were treated with alum, PAC, Percol 720 and Percol 778, and then added to Aureococcus anophagefferens cultures.

Pulsed clay addition and agitation experiment. Two variations in the clay screening protocol were performed using Aureococcus anophagefferens and selected clays (H-DP, MI-HY and IMC-P2). In the first experiment, the clay slurry was added to each cell suspension in a single pulse $(1 \mathrm{ml}), 2$ pulses $(2 \times 0.5 \mathrm{ml})$, 3 pulses $(3 \times 0.33 \mathrm{ml})$ and 4 pulses $(4 \times 0.25 \mathrm{ml})$, with 15 min between each pulse. The same total amount of clay was added in all cases. The reaction was terminated at $2.5 \mathrm{~h}$ and the final fluorescence measurement was taken as before. In the second experiment, the clays were added in a single pulse, after which the test tube was immediately capped and inverted 3 times to thoroughly disperse the clay and cell suspension. The tube was then placed upright on a rack and flocculation was allowed to proceed undisturbed for $2.5 \mathrm{~h}$. The final cell concentration and removal efficiency were determined as above.

Effect of clay treatment on viability and growth. The effect of IMC-P2 (phosphatic clay) on the viability and growth of Gymnodinium breve was studied using 3 strategies, 2 of which consider the role of physical resuspension on the ability of a treated cell to recover. In the first experiment, the clay-cell pellet was incubated in each tube for 2.5, 12, 24 and $48 \mathrm{~h}$ at $20^{\circ} \mathrm{C}$ following clay treatment $(0,0.03,0.10,0.50 \mathrm{~g}$ $\left.\mathrm{l}^{-1}\right)$. After the remaining cell concentration in the supernatant had been determined (by fluorescence), the supernatant was returned to the original tube and mixed well with the sedimented clay and cells. One milliliter aliquots were treated with $2.5 \mu \mathrm{M}$ (final) 5-chloromethylfluorescein diacetate (CMFDA) (Molecular Probes, Oregon), a vital stain that only penetrates the cell membrane of live cells and reacts with esterases to produce a green signal under FITC fluorescence (450 to $490 \mathrm{~nm}$ excitation, Zeiss axioscope). Samples were incubated at $20^{\circ} \mathrm{C}$ for $20 \mathrm{~min}$ in the dark. The first 400 cells encountered on the slide were counted, keeping track of living and dead (dying) cells. Dead cells were identified as intact cells without green FITC fluorescence, or easily discernible cell fragments that contain cytoplasmic material. 
In a second experiment, the supernatant was carefully returned to the original tube immediately after the fluorescence measurement without disturbing the pellet. The tubes were incubated at $20^{\circ} \mathrm{C}$ and cell growth was monitored over $150 \mathrm{~h}$ by making daily fluorescence measurements on the unmixed supernatant. The controls consisted of cultures treated with distilled/DI water $(1 \mathrm{ml})$ or $\mathrm{f} / 2$ medium $(1 \mathrm{ml})$.

For the third experiment, the goal was to determine whether potentially viable cells from the pellet can recover and grow if allowed to disaggregate from the pellet as a result of resuspension. After the supernatant had been removed, the clay-cell pellet was resuspended in fresh $\mathrm{f} / 2$ medium (10 $\mathrm{ml}$ final volume). The volume was distributed equally into 3 new test tubes and incubated for $24 \mathrm{~h}$ at $20^{\circ} \mathrm{C}$. The cultures were then subjected to a mixing schedule in which the pellet was resuspended daily, every $2 \mathrm{~d}$, or every $3 \mathrm{~d}$. Resuspension was achieved by gently mixing the tube by hand until the material on the bottom was evenly dispersed. Direct fluorescence measurements of the supernatant were taken daily over $7 \mathrm{~d}$ using fluorescence prior to each resuspension procedure.

Possible causes of cell mortality. This experiment was conducted to elucidate the possible cause(s) of Gymnodinium breve mortality following clay treatment. We tested whether a cytotoxic substance is released into the medium during the clay treatment. After $2.5 \mathrm{~h}$ clay treatment, the supernatant was filtered using a syringe filter holder with a Gelman A/E type glass-fiber filter $(0.7 \mu \mathrm{m})$. The filtrate was enriched with the appropriate amount of f/2 nutrients. Nine milliliters of the filtrate was transferred into test tubes and re-innoculated with an actively growing culture of $G$. breve. Cell growth was monitored over $6 \mathrm{~d}$ by fluorescence; $1 \mathrm{ml}$ of DI water was added to control tubes treated in the same fashion.

Other HAB species. The removal ability of IMC-P2 was further tested against 2 additional species following the previous screening protocol: Alexandrium tamarense (GTCA 28) and Heterosigma akashiwo (CCMP 452).

\section{RESULTS}

\section{Clay screening}

The removal efficiency of clays against Gymnodinium breve generally followed a hyperbolic function with clay concentration (Fig. 1A). A cluster analysis based on initial slope of the removal plots revealed that the clays could be placed into 4 groups (Fig. 1A, Table 1). Twelve clays (Group 1) reached $>90 \%$ removal efficiency at the lowest concentration tested $\left(0.25 \mathrm{~g} \mathrm{l}^{-1}\right)$, after which removal remained constant. This group consisted of all Florida phosphatic clays, several montmorillonites and bentonites, 1 kaolinite and 1 zeolite. Further tests with IMC-P2 phosphatic clay showed that removal efficiency can reach $80 \%$ with as little as $0.04 \mathrm{~g}^{-1}$ (Fig. 2). The remaining clays were placed in 3 groups that displayed less efficient removal rates, with Group 4 showing a more linear removal relationship with clay concentration (e.g. Korean Loess clay).

In contrast, the removal efficiency of all clays against Aureococcus anophagefferens did not exceed $36 \%$ at $0.25 \mathrm{~g} \mathrm{l}^{-1}$ (Fig. 1B). Loess clay (LO), Huber kaolinite (HDP) and Milwhite attapulgite (MI-HY) displayed the
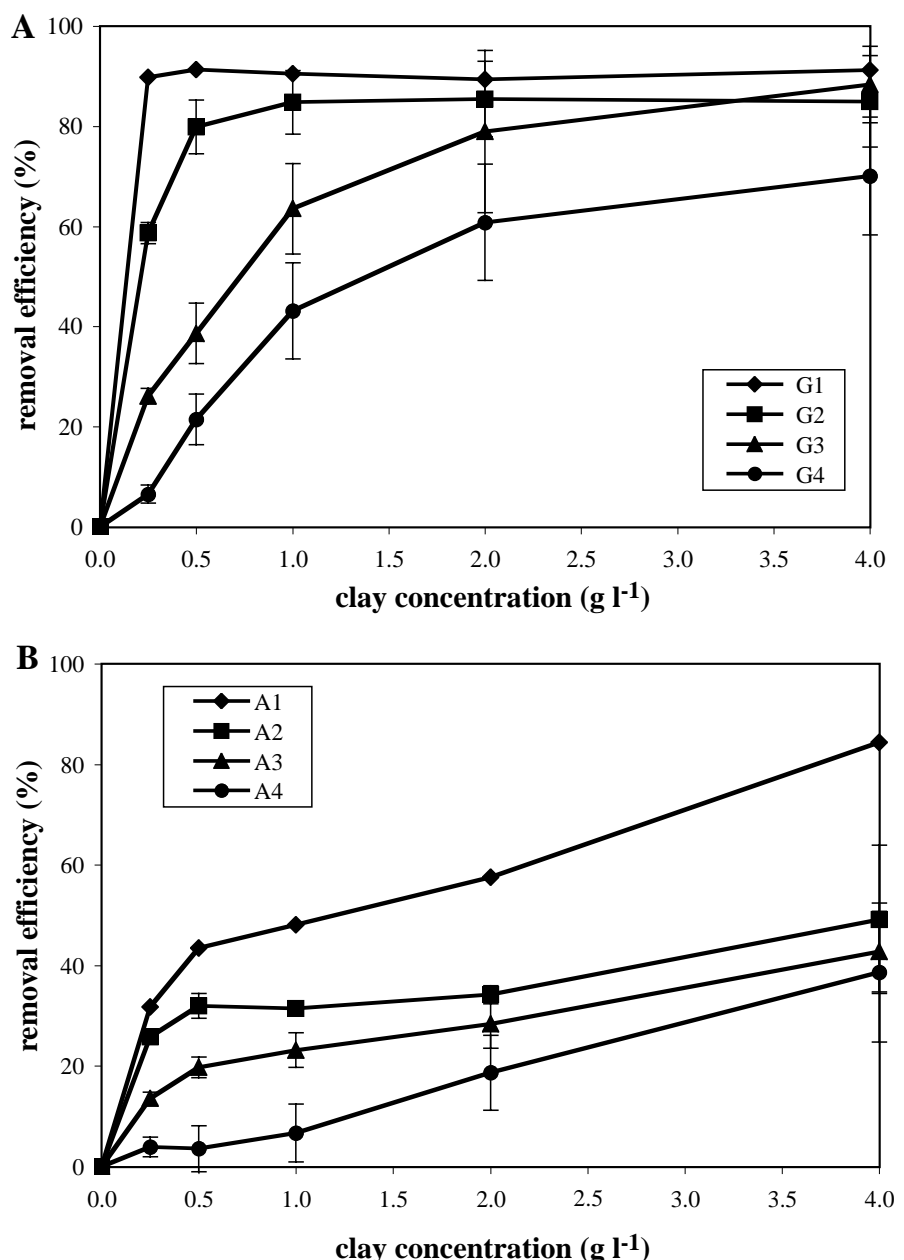

Fig. 1. Removal efficiency of domestic clays against (A) Gymnodinium breve and (B) Aureococcus anophagefferens. Clays were grouped by comparing the initial slope of each removal curve (from 0 to $0.25 \mathrm{~g} \mathrm{l}^{-1}$ ). Slopes were analyzed using cluster analysis (Statistica) based on linkage distances. These curves represent the best fit curve for each cluster. G1-G4: clay groupings based on the removal of $G$. breve; A1-A4: clay groupings based on the removal of $A$. anophagefferens. The clays comprising each group are listed in Table 1 


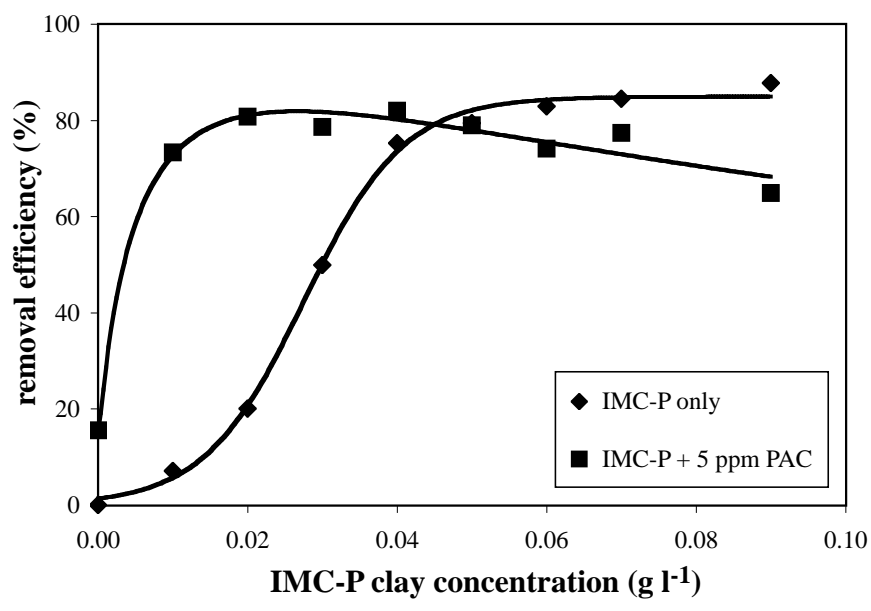

Fig. 2. Removal efficiency of IMC-P2 alone and IMC-P2 treated with polyaluminum chloride (PAC) against Gymnodinium breve. Lower clay amounts were tested $\left(<0.25 \mathrm{~g} \mathrm{l}^{-1}\right)$

best removal at this concentration. At higher concentrations, removal efficiency increased linearly with increasing clay dosage, and the highest removal observed was $86.6 \%$ using $4.0 \mathrm{~g} \mathrm{l}^{-1}$ (LO, Group 1).

\section{Coagulants and flocculants}

The removal efficiency of alum, PAC and both cationic flocculants (Percol LT-7990 and LT-7991) against Gymnodinium breve did not exceed $49 \%$ within the concentration range tested (Fig. 3A). Similarly, alum, PAC and the organic flocculants (Percol 720 and 778) were ineffective against Aureococcus anophagefferens, with removal rates reaching only $10 \%$. In the case of Percol 778, removal efficiency was negative, which suggested that the flocculant prevented cell sinking relative to the controls (= stabilization). Percol 720 displayed a similar effect between 3 and $10 \mathrm{ppm}$, but to a lesser extent.

\section{Clays plus coagulants/flocculants}

The addition of alum and Percol to IMC-P2 phosphatic clay decreased its removal efficiency of Gymnodinium breve (Table 2). The addition of $>10 \mathrm{ppm}$ Percol LT-7990 and LT-7991 resulted in a decrease in removal efficiency from 89 to $50 \%$, and from 85 to $46 \%$, respectively. The clay suspension flocculated with itself immediately after addition of the coagulant or flocculant, before it could be added to the cultures. Vigorous shaking and vortexing of the clay slurry could not disrupt the particles. After the slurry was added to the culture, clay flocs formed quicker and were much greater in size than untreated clays. These particles sank more rapidly to the bottom of the test tube.

In contrast, the removal efficiency of IMC-P2 phosphatic clay was greatly enhanced by the addition of PAC (Fig. 2). It took $90 \%$ less clay to achieve an $80 \%$ removal with the addition of $5 \mathrm{ppm}$ of PAC (cf. $0.01 \mathrm{~g}$ $1^{-1}$ clay with and without PAC: Fig. 2).

In the study, the zeolite SW-NZ displayed one of the lowest removal rates against Gymnodinium breve $(20 \%$ at $2.0 \mathrm{~g} \mathrm{l}^{-1}$ ). The addition of alum to this 'ineffective' clay increased its removal efficiency relative to clay alone (Table 2), but decreased to negative values between 10 and $100 \mathrm{ppm}$, suggesting the stabilization effect observed in the prior experiment (i.e. Percol 778 alone against Aureococcus anophagefferens). The combina-

Table 2. Removal efficiency of clays treated with surfactants against Gymnodinium breve. $0.10 \mathrm{~g} \mathrm{l}^{-1}$ of IMC-P2 phosphatic clay (highly effective) and SW-NZ zeolite (ineffective) were pre-treated with increasing dosage of aluminum sulfate (Alum), Percol LT-7990 and Percol LT-7991 prior to addition to cell suspension. For removal efficiency, standard errors $(n=3)$ are given in parentheses

\begin{tabular}{|c|c|c|}
\hline $\begin{array}{l}\text { Clay, } \\
\text { Surfactant }\end{array}$ & $\begin{array}{l}\text { Surfactant } \\
\text { conc. (ppm) }\end{array}$ & $\begin{array}{c}\text { Removal } \\
\text { efficiency (\%) }\end{array}$ \\
\hline \multicolumn{3}{|c|}{ IMC-P2 phosphatic clay $\left(0.10 \mathrm{~g} \mathrm{l}^{-1}\right)$} \\
\hline \multirow{5}{*}{ Alum } & Clay alone & $93.7(0.85)$ \\
\hline & 1 & $93.4(0.37)$ \\
\hline & 10 & $91.8(2.98)$ \\
\hline & 100 & $93.5(0.74)$ \\
\hline & 1000 & $67.6(2.41)$ \\
\hline \multirow[t]{5}{*}{ Percol LT-7990 } & Clay alone & $89.2(2.29)$ \\
\hline & 1 & $88.8(3.08)$ \\
\hline & 10 & $50.0(2.44)$ \\
\hline & 100 & $51.2(2.31)$ \\
\hline & 1000 & $64.6(4.31)$ \\
\hline \multirow[t]{5}{*}{ Percol LT-7991 } & Clay alone & $85.4(1.87)$ \\
\hline & 1 & $65.4(3.74)$ \\
\hline & 10 & $46.2(2.44)$ \\
\hline & 100 & $42.7(8.06)$ \\
\hline & 1000 & $28.6(7.29)$ \\
\hline \multicolumn{3}{|c|}{ SW-NZ Southwestern 'Natur' zeolite $\left(0.10 \mathrm{~g} \mathrm{l}^{-1}\right)$} \\
\hline \multirow[t]{5}{*}{ Alum } & Clay alone & $1.5(4.35)$ \\
\hline & 1 & $5.7(5.21)$ \\
\hline & 10 & $-4.9(5.21)$ \\
\hline & 100 & $-1.7(4.52)$ \\
\hline & 1000 & $3.5(7.53)$ \\
\hline \multirow[t]{5}{*}{ Percol LT-7990 } & Clay alone & $1.5(4.35)$ \\
\hline & 1 & $-2.9(8.81)$ \\
\hline & 10 & $0.5(0.00)$ \\
\hline & 100 & $28.1(7.98)$ \\
\hline & 1000 & $33.4(6.76)$ \\
\hline \multirow[t]{5}{*}{ Percol LT-7991 } & Clay alone & $1.5(4.35)$ \\
\hline & 1 & $-7.4(7.73)$ \\
\hline & 10 & $12.4(4.13)$ \\
\hline & 100 & $39.0(12.43)$ \\
\hline & 1000 & $35.6(2.12)$ \\
\hline
\end{tabular}



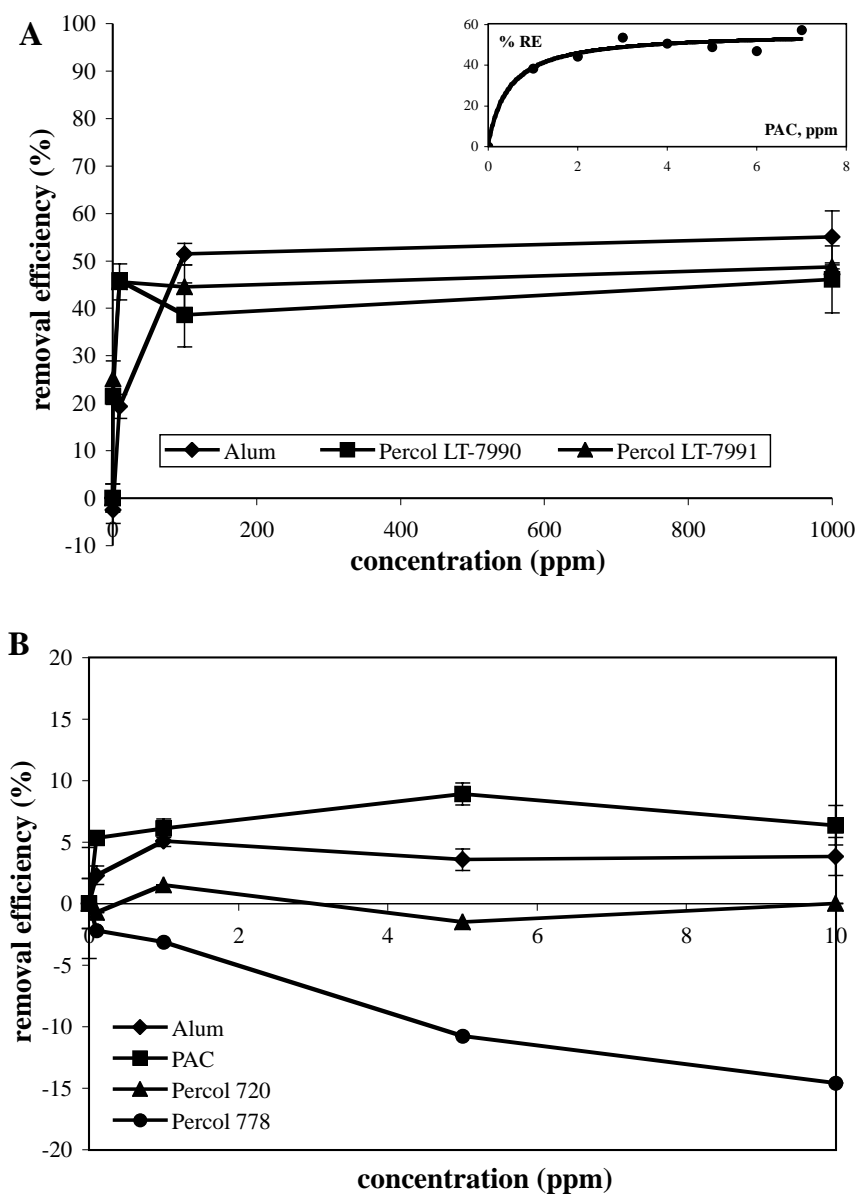

Fig. 3. Removal efficiency (RE) of inorganic coagulants (alum and polyaluminum chloride $=$ PAC) and organic flocculants (Percol 720, 778, LT-7990, LT-7991) against (A) Gymnodinium breve and (B) Aureococcus anophagefferens. Inset: PAC removal curve against $G$. breve

tion of $0.50 \mathrm{~g} \mathrm{l}^{-1}$ of SW-NZ and $100 \mathrm{ppm}$ of either Percol LT7990 or 7991 greatly improved removal efficiency compared to the clay alone (from 30 to $49 \%$; data not shown). However, this improvement is equivalent to the removal efficiency of either polymer alone.

In this study, there was no combination of clay and coagulant/flocculant that showed significant improvement in the removal of Aureococcus anophagefferens (data not shown).

\section{Pulsed clay addition and mixing}

Sequential pulsed addition of clays did not significantly improve the removal of Aureococcus anophagefferens using H-DP kaolinite (Fig. 4). However, the single clay pulse followed by agitation immediately after addition produced higher removal efficiency. This variation in the protocol was the only improvement observed in the removal of $A$. anophagefferens with clays throughout this study. Normally, the clay suspension is added gently to the top of the tube, where it forms a layer that gradually sediments out.

\section{Viability and growth of Gymnodinium breve after clay treatment}

The number of living versus dead (dying) Gymnodinium breve cells based on vital staining is summarized in Fig. 5. Immediately after phosphatic (IMC-P2) clay addition $(2.5 \mathrm{~h})$, there were no dead cells detected in any of the treatments. Mortality increased dramatically after $12 \mathrm{~h}$, especially at 0.10 and $0.50 \mathrm{~g} \mathrm{l}^{-1}$. The number of dead cells was more difficult to count at higher clay loadings because most of the cells were lysed and became indistinguishable from the clay particles in the surrounding medium. Therefore, the mortality values at $0.50 \mathrm{~g} \mathrm{l}^{-1}$ are likely to be underestimates of cell death. By 24 and $48 \mathrm{~h}$, most of the cells were dead and lysed in the $0.50 \mathrm{~g} \mathrm{l}^{-1}$ treatment (Fig. 5). Cell death was minimal in the control and $0.03 \mathrm{~g} \mathrm{l}^{-1}$ treatment.

The recovery of Gymnodinium breve after treatment was inversely related to the clay dosage (Fig. 6). There was no difference between the growth of the controls (distilled water added to $\mathrm{f} / 2$ ) and $0.03 \mathrm{~g} \mathrm{l}^{-1}$ clay addition, although $67 \%$ of the cells had been sedimented by the clay compared to $0.03 \%$ for the controls (data not shown). Despite the similarity in ultimate cell yield, the culture treated with clay showed a $24 \mathrm{~h}$ delay in recovery. This delay increased to $48 \mathrm{~h}$ when the clay concentration was doubled to $0.06 \mathrm{~g} \mathrm{l}^{-1}$. Recovery and

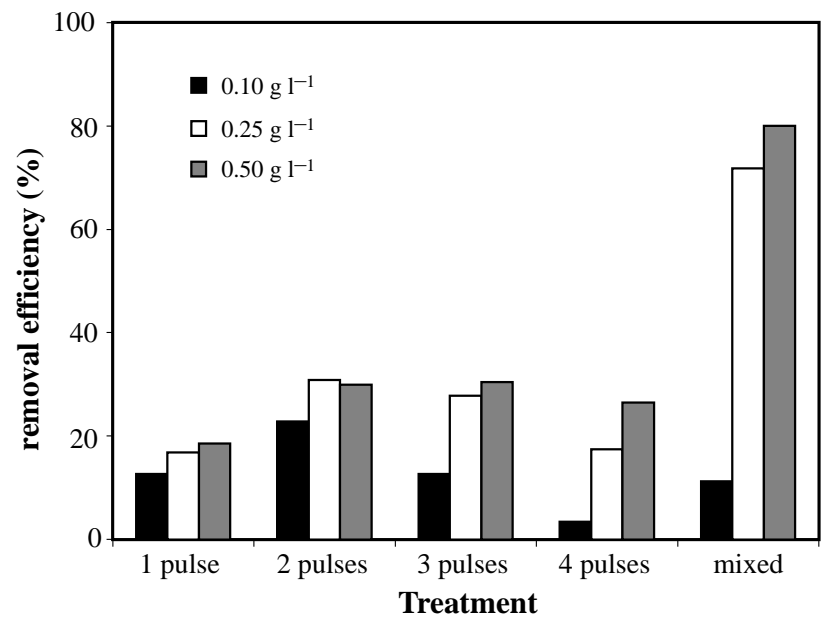

Fig. 4. Effect of agitation and pulsed clay addition on the removal efficiency of clays against Aureococcus anophagefferens. Clay pulses were added at 15 min intervals 


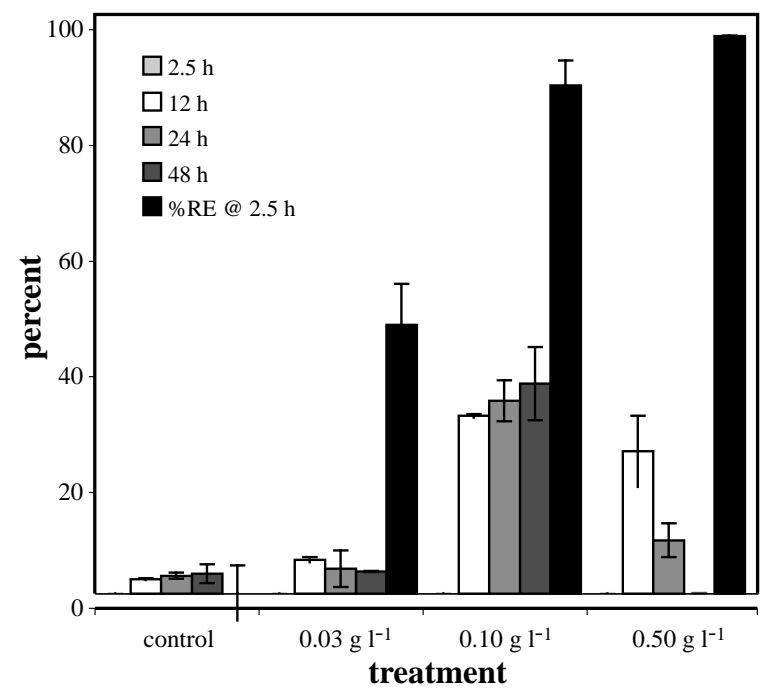

Fig. 5. Gymnodinium breve. Effect of clay treatment on viability. y-axis indicates the percent dead cells and the removal efficiency (RE) at $2.5 \mathrm{~h}$. Cell viability was determined using 5chloromethylfluorecein diacetate staining at various intervals after clay addition $(2.5,12,24$ and $48 \mathrm{~h})$

growth ceased when the clay dosage exceeded $0.13 \mathrm{~g} \mathrm{l}^{-1}$ in the unmixed cultures.

In the resuspension experiments, the fluorescence values were plotted against time for each experiment, and the best-fit regression lines through the points were calculated (data not shown). The slope of these lines was then compared statistically using a Student's $t$-test. No difference was found in the slope values among the 3 mixing schedules within each clay treatment, except for $0.10 \mathrm{~g} \mathrm{l}^{-1}$ (Table 3). At this dosage, there was a significant difference between daily mixing and every $3 \mathrm{~d}$ mixing, and between 2 and $3 \mathrm{~d}$ mixing. Following the comparisons of mixing frequency

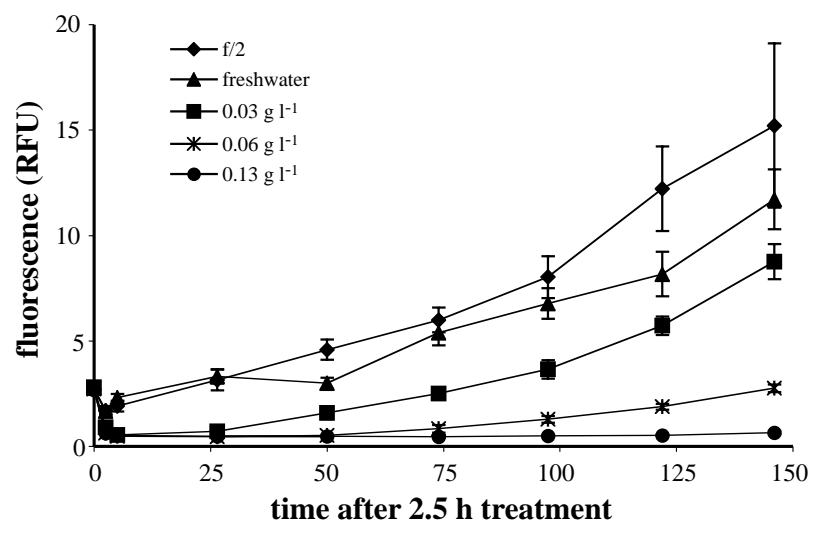

Fig. 6. Gymnodinium breve. Long-term growth following clay treatment. RFU: relative fluorescence units
Table 3. Gymnodinium breve. Resuspension experiment to determined cell recovery after treatment with IMC-P2 phosphatic clay. Results were analyzed statistically using linear regression and Student's $t$-test (Sigmastat). Within each clay treatment, there was no significant difference among the 3 mixing schedules (daily, every $2 \mathrm{~d}$ and every $3 \mathrm{~d}$ ) except at $0.10 \mathrm{~g} \mathrm{l}^{-1}$ loading. Subsequently, all data for each treatment were combined $(\mathrm{n}=21)$, except for $0.10 \mathrm{~g} \mathrm{l}^{-1}$ data set, in which they were considered separately $(n=7)$. Data below represent mean slope (change in cell concentration/time) of the linear regression for each treatment, standard error and sample size (n). Cell concentration was determined by fluorescence. Slopes were compared by a pairwise Student's $t$-test. Treatments with same letter did not differ significantly from each other $(\mathrm{p}>0.05)$, treatments with different letter differed significantly

\begin{tabular}{|lcrr|}
\hline $\begin{array}{l}\text { Treatment } \\
\left(\mathrm{g} \mathrm{l}^{-1} \text { ) }\right.\end{array}$ & $\begin{array}{c}\text { Mean slope } \\
\text { (change in cell density } \mathrm{t}^{-1} \text { ) }\end{array}$ & (n) & SE \\
\hline 0.00 & $43.33(\mathrm{~A})$ & $(21)$ & 2.14 \\
0.01 & $47.48(\mathrm{~A})$ & $(21)$ & 4.50 \\
0.10 (daily) & $127.74(\mathrm{~B})$ & $(7)$ & 6.91 \\
0.10 (every 2 d) & $124.12(\mathrm{~B})$ & $(7)$ & 5.54 \\
0.10 (every 3 d) & 90.57 (C) & $(7)$ & 2.55 \\
0.20 & 248.7 (D) & $(21)$ & 14.54 \\
0.50 & 9.72 (E) & $(21)$ & 1.45 \\
& & & \\
\hline
\end{tabular}

within each clay treatment, the data showing no statistical differences were grouped together and a new regression line was determined. The slope values were then compared among the different clay loadings (Table 3). There was no difference between the control and the lowest loading $\left(0.01 \mathrm{~g} \mathrm{l}^{-1}\right)$. At $0.20 \mathrm{~g} \mathrm{l}^{-1}$, the large slope value was observed which seemed to indicate that a large number of cells escaped from the floc and recovered. The lowest slope value was found at $0.50 \mathrm{~g} \mathrm{l}^{-1}$, suggesting low cell recovery. At the intermediate amount of clay $\left(0.10 \mathrm{~g} \mathrm{l}^{-1}\right)$, the recovery seems to be determined by the frequency of mixing: cell recovery was greatest when the pellet was resuspend daily or within $2 \mathrm{~d}$ after treatment. Survival of the cells decreased when the pellet was mixed after the third day.

\section{Causes of mortality}

Growth of Gymnodinium breve in the clay-treated (filtered) medium was no different from that of controls over the entire range of clay loadings (Fig. 7). Clearly, mortality was not due to the release of toxicants.

\section{Removal of other HAB species}

IMC-P2 phosphatic clay displayed varying removal ability for the different HAB species tested (Fig. 8). As 
Fig. 7. Gymnodinium breve. Cell growth in conditioned seawater following $G$. breve/clay experiment. One control corresponded to clay-treated seawater $\left(0.10 \mathrm{~g} \mathrm{l}^{-1}\right)$ without cells, while second control contained cells treated with $1 \mathrm{ml}$ distilled/deionized water without clay

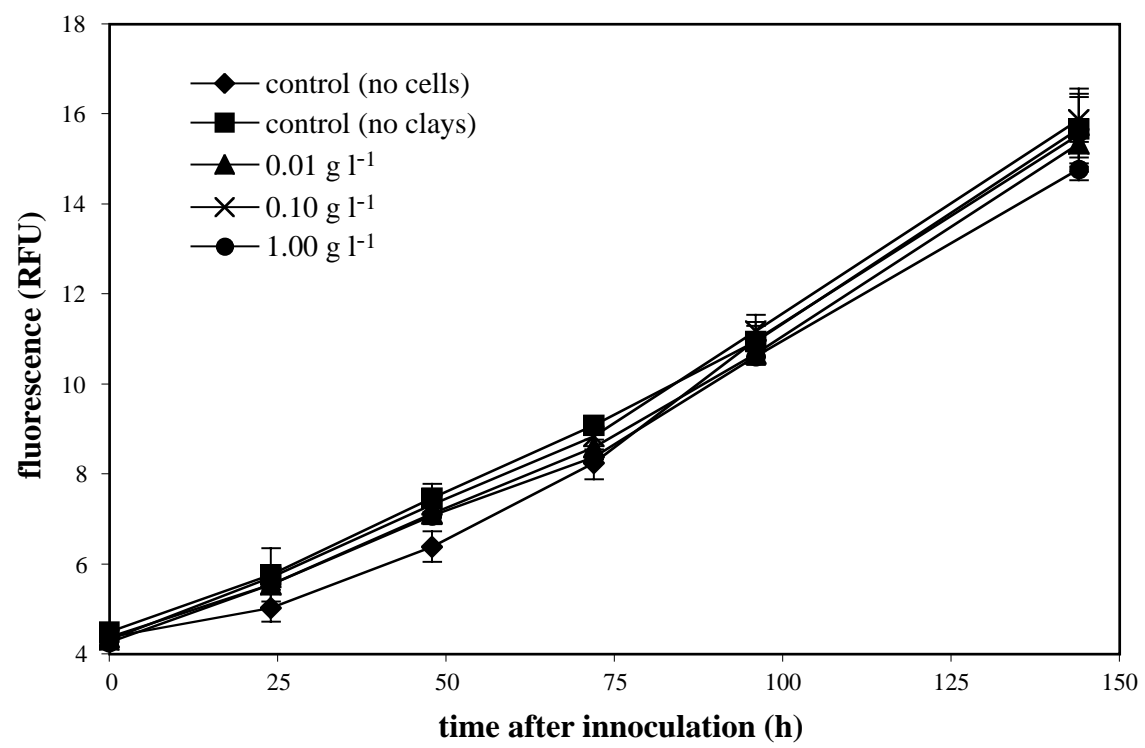

with Gymnodinium breve, Heterosigma akashiwo was removed with high efficiency. Moderate removal was found with Alexandrium tamarense.

\section{DISCUSSION}

\section{Clay screening}

This study demonstrated that different clay minerals have different removal ability for the range of HAB species tested. In addition, a clay mineral that exhibits high removal efficiency against one organism may not behave similarly against another organism. Therefore, the most suitable clay(s) for a given target species must be determined empirically.

In the case of Gymnodinium breve, the most effective clays were the bentonites, montmorillonites, and the Florida phosphatic clays which mostly contain montmorillonite (Bromwell 1982). Their removal curves followed a hyperbolic function that quickly plateaued near $90 \%$ efficiency after exceeding $0.25 \mathrm{~g} \mathrm{l}^{-1}$ loading (Fig. 1). Structurally, these clays are composed of 3 sheet-like layers which have a high swelling index (i.e. the ability to absorb and retain water between the layers, causing an expansion in the crystal). This property may increase the contact frequency between the clay particles and the algal cells, since larger particles can sweep through a larger surface than smaller particles.

By comparison, the zeolites and kaolinites have low swelling indices which may explain why these clays have much lower removal efficiencies against Gymnodinium breve (Table 1). However, 1 zeolite (SW-NM) and 1 kaolinite (H-DP) displayed removal ability comparable to the clays in Group 1. SW-NM appeared as a very fine powder compared to the other zeolites, which seemed coarser and contained sand-sized grains. SW-NM remained in suspension longer, while the others sank rapidly, allowing the former to have more possible interactions with the algae. On the other hand, the effectiveness of H-DP may be explained by surface chemistry and a potentially higher affinity for the cells. H-DP is the only clay tested which was treated with strong acids during its production. In fact, the clay suspension prepared with distilled/DI water $(\mathrm{pH}=6.98)$ was acidic $(\mathrm{pH}=4.86)$, indicating that the clays may carry residual protons

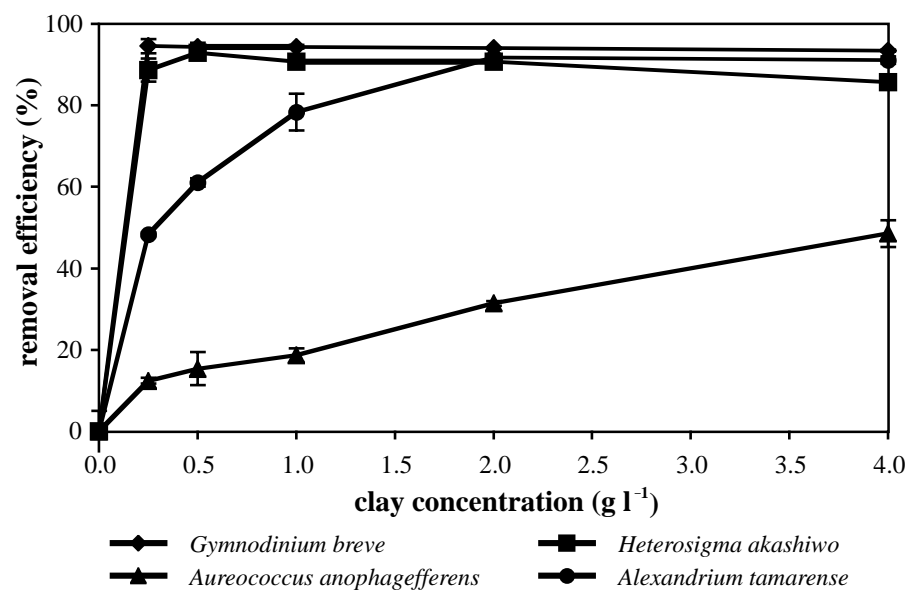

Fig. 8. Removal efficiency of IMC-P2 (Florida phosphatic clay) against several harmful algal bloom species 
which were later released into the medium. This charge on the clay surface may increase its 'stickiness' or surface reactivity with the algal cells.

Moreover, H-DP was the clay which displayed one of the best removal efficiencies (at $0.25 \mathrm{~g} \mathrm{l}^{-1}$ ) against Aureococcus anophagefferens, although the values did not exceed $40 \%$. Loess clay (LO, kaolinite) and MI-HY (attapulgite) produced similar results (Fig. 1B). In this study, $85 \%$ was the highest removal efficiency observed and was achieved with $4.0 \mathrm{~g} \mathrm{l}^{-1}$ of Loess clay, 16 times more clay than in Gymnodinium breve. As with $G$. breve, the zeolites were ineffective against $A$. anophagefferens (data not shown). Aside from this observation, however, there was no clear pattern between removal effectiveness and mineral type (montmorillonite/bentonite vs kaolinite; data not shown).

This resistance of Aureococcus anophagefferens to clay flocculation may be explained by 2 physico-chemical factors: (1) lower contact efficiency due to low 'stickiness' of the organism, and (2) low contact frequency between clays and cells due to the small cell size (ca $2 \mu \mathrm{m}$ ). Direct measurements of algal 'stickiness' are difficult to make, and there have been no determinations for $A$. anophagefferens. Therefore, this conjecture must be addressed in a future report. In the second hypothesis, the small size of the organism is a critical factor. The contact frequency between the particles is governed by 3 factors (O'Melia \& Tiller 1993): Brownian diffusion, water motion (laminar and turbulent), and differential sedimentation. In this system, Brownian diffusion can be disregarded since it is insignificant when particles exceed $1 \mu \mathrm{m}$. Likewise, the effect of water motion is minimal since flocculation proceeded under quiescent conditions. Thus, the number of clay-cell contacts will be dominated by differential sedimentation (collisions produced when smaller particles are intercepted by larger, more rapidly sinking particles). For this to occur, a difference in size between particles is necessary to create particles with different sinking rates. However, as the size of one particle greatly exceeds that of the other, the larger particle displaces more water (hydrodynamic effect), making it more difficult for the smaller particle to approach, interact and bind with the larger one (Thomas et al. 1999). With this reasoning, we hypothesized that clayclay flocculation occurred at the water surface after it was added to the culture. As the clay flocs sank through the water column, they interacted with the cells and removed them. As the floc size increased along the tube and greatly surpassed the cells' size, the contact frequency between the cells and clays diminished, leaving most of the cells behind. This is consistent with our observation that by gentle mixing of the cell/clay suspension just after clay addition - a process that kept initial clay size small and increased the collision rates (by turbulent water motion) - significantly more $A$. anophagefferens were removed from the medium (Fig. 4). Therefore, we favor this explanation at this juncture.

\section{Coagulants/flocculants without clays}

While coagulants and flocculants are highly effective in water-treatment facilities in flocculating and quickening the removal of fine suspended particles, the substances tested in this study were ineffective against Gymnodinium breve (51\% removal efficiency) and Aureococcus anophagefferens (10\% removal efficiency) (Fig. 3). In theory, coagulants and flocculants promote flocculation by affecting the surface chemistry (stickiness) of the particles. Coagulants reduce electrostatic repulsion by collapsing the electrical double layer surrounding the charged particle, allowing attractive forces and aggregation to dominate. Flocculants can induce flocculation by acting as interparticle bridges between 2 or more particles which may otherwise repel one another. Indeed, the addition of these substances may have increased the propensity towards flocculation during the experiment. However, increasing the flocculation rate would also require an increase in interparticle contacts (e.g. through mixing or agitation), which was not altered in these experiments. Moreover, the addition of clays would have increased the total number of particles in the system (in the order of $10^{13}$ to $10^{15} 1 \mu \mathrm{m}$-sized particles), and hence, the chance of collisions producing larger particles. Without interparticle contacts to create progressively larger particles, the addition of coagulants and flocculants produced no apparent effects on the system.

Other explanations include spatial separation between the substances added at the surface (unmixed), and the target cells distributed throughout the medium. Alternatively, the high ionic strength and alkalinity of the seawater may have rendered the chemicals ineffective or inert.

In the case of Aureococcus anophagefferens treated with flocculants (Percol 720 and 778), negative values of removal efficiency were found (Fig. 3B). Based on the method of calculating removal (Eq. 1), we concluded that the cells treated with flocculant sank less than those in the control (no flocculant). This result suggested that the system became more stable, and sinking was retarded through an increase in seawater viscosity originating from the addition of flocculant itself. This effect was apparent after the experiment when cultures were discarded and the seawater in the tubes appeared thicker and more difficult to pour out. 


\section{Coagulants/flocculants with clay}

The most effective clays and 1 ineffective clay were treated with varying amounts of coagulants and flocculants prior to being added to the cell suspension. This combination was predicted to enhance the clays' effectiveness by increasing their chemical affinity (or stickiness) for the HAB cells. In the case of Gymnodinium breve and IMC-P2, a highly effective clay, the addition of PAC at 5 ppm enhanced removal efficiency by 1 order of magnitude (Fig. 2). In contrast, alum, Percol LT-7990 and Percol LT-7991 reduced removal efficiency. The primary effects of adding these chemicals above $10 \mathrm{ppm}$ were the rapid flocculation of the clay slurry prior to addition, the apparent increase in clayclay flocculation, and the rapid sedimentation of the flocs, thereby limiting their residence time in the water column and the potential contacts with cells.

The addition of coagulants/flocculants slightly enhanced the removal of SW-NZ zeolite against Gymnodinium breve (from 20 to $50 \%$ ). However, the higher values only matched those attained when flocculant was added alone (Table 2). Nevertheless, this improvement demonstrates the potential usefulness of coagulants and flocculants, especially in the case of PAC and IMC-P2. Interestingly, PAC alone was not effective (Fig. 3A: inset). The explanations for this observation may be similar to those offered in the previous section, where coagulants and flocculants were used alone. In this example, the addition of PAC enhances the chemical interaction of the surface, but the clays themselves act as the 'ballast' which eventually promotes the sinking of the cell.

The various combinations of clay and coagulants/flocculants against Aureococcus anophagefferens were all ineffective (data not shown). Likewise, the gradual and sequential addition of clays did not produce a significant increase. The only substantial improvement in removal efficiency occurred when H-DP was added to the culture and dispersed thoroughly in the medium by gently mixing (Fig. 4). Presumably this step increased interparticle collisions and prevented the flocs from growing too fast.

\section{Viability and growth of Gymnodinium breve after clay treatment}

Based on our studies, the mortality of Gymnodinium breve after treatment with IMC-P2 depended on 3 factors. In decreasing order of importance, survival was influenced by the clay loading, the duration of contact between cells and clays, and the opportunity of escape through resuspension. At relatively low clay loadings $\left(\leq 0.03 \mathrm{~g} \mathrm{l}^{-1}\right)$, cell mortality was small (Fig. 5), and the organisms were able to gradually, but completely, free themselves from the settled clay matrix, swim away, and resume vegetative growth. In Fig. 6, their escape is documented as a rapid increase in cell concentration within $24 \mathrm{~h}$, which cannot be explained by simple growth and division. Moreover, this escape can occur with or without the aid of manual resuspension.

At relatively high clay loadings $\left(\geq 0.50 \mathrm{~g} \mathrm{l}^{-1}\right)$, cell mortality rapidly increased after $2.5 \mathrm{~h}$ of exposure to the clay (Fig. 5). Despite the large number of cells contained within the clay matrix, few cells escaped. After $24 \mathrm{~h}$ without resuspension, most of the cells died (Fig. 5). This is also evident from the very low recovery in the mixing experiment, even with daily resuspension (Table 3).

The interplay of clay dosage, duration of contact and resuspension is more complicated at intermediate clay loadings (0.05 to $0.25 \mathrm{~g} \mathrm{l}^{-1}$ ). Cell death markedly increases with increasing dosage, with significant mortality after $2.5 \mathrm{~h}$, especially if resuspension does not occur in the first $24 \mathrm{~h}$ (Fig. 5, Table 3). At $0.06 \mathrm{~g} \mathrm{l}^{-1}$, the cells survived and escaped the clay matrix without resuspension, although their recovery was delayed by $48 \mathrm{~h}$ (twice the amount of time for double the clay loading (Fig. 6). At $0.13 \mathrm{~g} \mathrm{l}^{-1}$ with no resuspension, no recovery was seen even after $6 \mathrm{~d}$ (Fig. 6). However, if resuspension took place within $3 \mathrm{~d}$ after clay addition, the cells survived and recovered, although their subsequent growth was better if resuspension happened sooner (Table 3). Finally, at $0.20 \mathrm{~g} \mathrm{l}^{-1}$ (Table 3), escape and recovery did not take place without resuspension (Fig. 6, same as at $0.13 \mathrm{~g} \mathrm{l}^{-1}$ ), but the cells survived in the matrix and grew even after waiting $3 \mathrm{~d}$ before resuspending the pellet.

A preliminary investigation on the possible cause of cell mortality did not indicate the release of cytotoxic substances from the clay into the surrounding medium. Moreover, fresh Gymnodinium breve cultures innoculated into conditioned water (i.e. water filtered following clay treatment) did not show growth inhibition or cell loss (Fig. 7). Cell death and lysis was evident within the settled clay matrix from vital staining and direct microscopic observation. The cells appeared moribund, and stained cytoplasmic material could be seen leaking into the medium. We conclude that cell death was caused by the direct physical contact between the cells and clays at very high dosage and over extended periods of time. However, the exact means by which surface interactions can lead to cell death remains unknown. In earlier studies, cell lysis by clays may have resulted from the presence of prosthetic groups, such as aluminum, on the clay surface. Shirota (1986) argued that aluminum released from clays can cause fragile cells to lyse. Alternatively, acid/base reactions on the clay surface can lead to 
rapid changes in $\mathrm{pH}$ which may cause serious damage to the integrity and function of the cell membrane.

\section{Phosphatic clays}

Despite differences in their geographic origins and methods of processing, the 5 samples of Florida phosphatic clays exhibited consistently high, statistically similar removal efficiencies of Gymnodinium breve (Table 1). They are a by-product of phosphate mining, a major industry across central and southern Florida. The 'clay' itself is a freshwater suspension, composed of silt and sand (30 to $50 \%$ ), and a so-called clay-sized fraction $(<2 \mu \mathrm{m})$ making up to two-thirds of the solid mass (Bromwell 1982). The major minerals in the clay fraction are smectite (i.e. montmorillonite, 8 to $32 \%$ ), illite ( 0 to $14 \%$ ), palygorskite ( 0 to $23 \%$ ) and kaolinite (0.8 to $1.9 \%$ ), with some minor minerals such as wavellite, crandellite, dolomite/calcite, feldspar, millisite, iron phosphates and trace amounts of various metals (Barwood 1982). Generally, the material leaves the beneficiation plant as a slurry of $3 \%$ solids, which is then stored in ponds for settlement and dewatering, producing clay with up to $55 \%$ solids in older basins. This clay material is the most promising choice against the Florida red-tide organism, not only because of its effectiveness, but also because of its availability in the affected region and the large available supply of the material.

Presently, there is no clear explanation to account for the effectiveness of this clay. It is similar to the other clays in Group 1 in that montmorillonite is its main constituent mineral. One reason may lie in its chemical composition, which may include organic matter that can enhance its 'stickiness'. Microscopic videography of the clay-cell flocculation in situ showed that the organisms seemed to adhere quickly and strongly to the clay flocs upon contact, becoming trapped and reducing the chance of escape during their rapid descent. These issues are currently being investigated.

Lastly, the phosphatic clays appeared to have varying affinity towards different HAB species (Fig. 8). Gymnodinium breve and Heterosigma akashiwo were highly affected, while Alexandrium tamarense was only moderately removed. The clay seemed ineffective against Aureococcus anophagefferens. This characteristic may have practical implications in clay use: it demonstrates the versatility of the clay to target specific HAB organisms and not to remove all algae species indiscriminately.

\section{Potential for clays in HAB management}

This study demonstrated that clays can effectively remove a number of $\mathrm{HAB}$ species that threaten US coasts. For example, the Florida phosphatic clays are very effective against Gymnodinium breve because of their consistent effectiveness at low loading. Clay loading may be further reduced by adding minute amounts of PAC, a chemical additive approved for drinking water treatment (ANSI/NSF Standard 60). Clay treatment can also kill cells at the relevant dosages and could minimize the chance of bloom recurrence. Moreover, these clays displayed varying removal ability against different algae species, suggesting the possibility of selective removal. Logistically, clay is a suitable mitigation candidate because it is plentiful, inexpensive, and readily available close to the area where it may be used in Florida. Phosphatic clay also showed promise against Heterosigma akashiwo, although more tests are needed.

Assuming that removal efficiency for phosphatic clays remains constant with increasing dimensions and scale of the water column, a target clay loading of $0.05 \mathrm{~g} \mathrm{l}^{-1}$ (without coagulant) would remove $85 \%$ of Gymnodinium breve cells. For a basin with a surface area of $1 \mathrm{~km}^{2}$ cleared to a depth of $4 \mathrm{~m}$ (total volume $=4.0 \times 10^{6} \mathrm{~m}^{2}$ or $4 \times 10^{9} \mathrm{l}$ ), approximately $200 \mathrm{t}$ of clay would be required for 1 treatment. If all this material fell straight to the bottom and deposited evenly over the given surface area, the loading would be $200 \mathrm{~g} \mathrm{~m}^{2}$. Realistically, winds and currents would undoubtedly spread this loading over a much larger area. Finally, the addition of PAC to phosphatic clay can reduce the target loading to $0.01 \mathrm{~g} \mathrm{l}^{-1}$ (75\% removal efficiency), giving a mass of $40 \mathrm{t}$ of clay, which would settle and cover the bottom at $40 \mathrm{~g} \mathrm{~m}^{2}$.

The case is not so clear for Aureococcus anophagefferens. While higher removal efficiencies were finally attained for this organism (i.e. $80 \%$ with H-DP kaolinite), mixing and thorough dispersal of the clay into the medium were necessary. This step required energy and may create logistical and practical complications if the clay is to be used in the field. Future progress in the use of clay against this species may rely on a better understanding of the mechanism of removal and the factors that influence the clay-cell flocculation, some of which may have been identified during this study (i.e. contact rate, initial size of the clay particle, surface charge effects).

Finally, we recognize the need to investigate the possible impacts of clay addition to the marine environment and ecosystem, especially in the benthos. New studies are currently underway that address these issues. These and other projects will be critical in providing the scientific data needed to evaluate the possible use of clays in mitigating the impacts of HABs. 
Acknowledgements. The authors are grateful to the clay companies that provided samples for this study, especially $\mathrm{Mr}$ John Keating at IMC Agrico in Florida. We also acknowledge the contributions of Cytec Industries (Charlotte, NC) and Ciba Specialty Chemical (Suffolk, VA) in providing samples of coagulants and flocculants. We would like to thank the member of the Anderson laboratory at WHOI and 4 anonymous reviewers for their helpful discussions and insights. This research was funded by the Sholley Foundation, Inc., the United States Environmental Protection Agency, and the Morris Family Foundation. Support for K.T. was provided by the Woods Hole Summer Student Fellowships. Graduate support for M.R.S. was provided by the Ford Foundation Fellowships and the Woods Hole Education Office. This report is contribution number 16 of the US ECOHAB Program, sponsored by NOAA, NSF, EPA, NASA and ONR, funded by the EPA Cooperative Agreement CR 827090-01-0 to D.M.A. and is contribution number 10142 for the Woods Hole Oceanographic Institution.

\section{LITERATURE CITED}

Anderson DM (1997) Turning back the harmful red tide. Nature 388:513-514

Anderson DM, Kulis DM, Keafer BA, Berdalet B (1999) Detection of the toxic dinoflagellate Alexandrium fundyense (Dinophyceae) with oligonucleotide and antibody probes: variability in labelling intensity with physiological condition. J Phycol 35:870-883

Avnimelech Y, Troeger BW, Reed LW (1982) Mutual flocculation of algae and clay: evidence and implication. Science 216(4541):63-65

Barwood HL (1982) Mineralogy and chemistry of phosphatic clays. In: Clark SW (ed) Phosphatic Clay Workshop. Florida Institute of Phosphate Research, Bartow, p 30-41 (FIPR Publ. No. 02-020-012)

Bromwell LG (1982) Physico-chemical properties of Florida phosphatic clays. Florida Institute of Phosphate Research, Bartow (FIPR/PUB-02-003-020)

Cosper EM, Lee C, Carpenter EJ (1990) Novel 'brown tide' blooms in Long Island embayments: a search for the causes. In: Graneli E, Sundstrom B, Edler L, Anderson DM (eds) Toxic marine phytoplankton. Elsevier, Berlin, p 17-28

Howell BR, Shelton RGJ (1970) The effect of China clay on the bottom fauna of St Austell and Mevagissey bays. J Mar Biol Assoc UK 50:593-607

Editorial responsibility: Otto Kinne (Editor), Oldendorf/Luhe, Germany
Landsberg JH, Steidinger KA (1998) A historical review of Gymnodinium breve red tides implicated in mass mortalities of the manatee (Trichechus manatus latirostris) in Florida, USA. In: Reguera B, Blanco J, Fernandez ML, Wyatt $\mathrm{T}$ (eds) Harmful algae. Xunta de Galicia and Intergovernmental Oceanographic Commission, UNESCO, Grafisant, Santiago de Compostela, p 97-100

McIntyre SC (1983) Flocculated algae, a potentially important food source for filter feeding fish. J Freshw Ecol 2(2): 193-196

Na G, Choi W, Chun Y (1996) A study on red tide control with Loess suspension. J Aquacult 9:239-245

O'Melia CR, Tiller CL (1993) Physicochemical aggregation and deposition in aquatic environments. In: Buffle J, Van Leeuwen HP (eds) Environmental particles, Vol 2. Lewis Publishers, Inc, Boca Raton, FL, p 353-386

Portman JE (1970) The effect of China clay on the sediments of St Austell and Mevagissey bays. J Mar Biol Assoc UK 50:577-591

Rounsefell GA, Evans JE (1958) Large-scale experimental test of copper sulfate as a control for the Florida red tide. US Fish and Wildlife Service, Washington, DC (Spec Sci Rep: Fish No 270)

Shirota A (1989a) Red tide problem and countermeasures (1). Int J Aquat Fish Technol 1:25-38

Shirota A (1989b) Red tide problem and countermeasures (2). Int J Aquat Fish Technol 1:195-223

Soballe DM, Threlkeld ST (1988) Algal-clay flocculation in turbid waters: variations due to algal and mineral differences. Verh Int Verein Limnol 23:750-754

Steidinger KA, Roberts BS Tester PA, Tomas CR, Vargo GA (1996) Red tide research planning and coordination meeting report. Nov 6-7 Department of Environmental Protection, Florida Marine Research Institute, St. Petersburg

Tester PA, Steidinger K (1997) Gymnodinium breve red tide blooms: initiation, transport, and consequences of surface circulation. Limnol Oceanogr 42:1039-1051

Thomas DN, Judd SJ, Fawcett N (1999) Flocculation modelling: a review. Water Res 33:1579-1592

Yu Z, Zou J, Ma X (1994a) Applications of clays to removal of red tide organisms. I. Coagulation of red tide organisms with clays. Chin J Oceanol Limnol 12:193-200

Yu Z, Zou J, Ma X (1994b) Applications of clays to removal of red tide organisms. II. Coagulation of different species of red tide organisms with montmorillonite and effect of clay pretreatment. Chin J Oceanol Limnol 12:316-324

Submitted: March 2, 2000; Accepted: July 27, 2000

Proofs received from author(s): January 8, 2001 